\title{
PENGGUNAAN AUKSIN ALAMI SEBAGAI \\ ZAT PENGATUR TUMBUH (ZPT) TERHADAPPERTUMBUHAN STEK BIBIT JAMBU AIR(Syszygium samarangense)
}

\author{
Bonefasius Rendo Dule ${ }^{1}$ ) dan Murdaningsih ${ }^{2}$ ) \\ $\left.{ }^{1}\right)$ Mahasiswa Universitas Flores,${ }^{2}$ ) Dosen Program Studi AgroteknologiFakultas Pertanian \\ Universitas Flores. J1. Sam Ratulangi - Paupire, Ende - Flores NTT \\ Email : Murdaningsih11@gmail.com
}

\begin{abstract}
Use of Natural Auksin as Growth Zat (ZPT) Against Growth of Stam Breeding Water Jamboo (Syszygium samarangense). This study aims to determine the effect of the use of auksin extract of onion, garlic extract and onion extract as well as the effect of the best extract on the growth of water cashew cuttings (Syzygium samarangense)

The study was arranged by Randomized Block Design with single factor pattern consisting of four treatments ie without auxin (A-0), auksin extract of onion (A-1), auksin garlic extract (A-2) and auksin garlic extract bombai (A-3). The observation variables in this study were: percentage of live cuttings $(\%)$, root length $(\mathrm{cm})$, root quantity, fresh root weight $(\mathrm{g})$, fresh weight weight $(\mathrm{g})$, dry root weight $(\mathrm{g})$ and dry weight weight $(\mathrm{g})$

The results showed the use of axin onion extract $90 \%$, can increase the percentage of live cuttings (2.99\%), root length (51.22\%); number of roots (56.55\%), fresh root weight (47.54\%); weight of fresh stover (26.22\%); dry root weight (51.72\%) and weight of dry stover $(27.64 \%)$. The use of $90 \%$ onion extract gave the best influence to the growth of root cashew cuttings which resulted in live cuttings percentage (98.86\%); root length $(10.04 \mathrm{~cm})$; number of roots $(19,20)$; fresh root weight $(2.02 \mathrm{~g})$; fresh fresh weight (17.22 g); dry weight of roots (1.06 g) and weight of dry stover $(8.60 \mathrm{~g})$.
\end{abstract}

\section{Keywords: natural auksin, water cashew cuttings}

\section{PENDAHULUAN}

Tanaman jambu air (Syszygium samarangense) dikenal sebagai tanaman asli Indonesia, yang merupakan tanaman umur panjang penghasil buah. Sejauh ini kegiatan pengembangan buah-buahan perlu didukung oleh tersedianya bibit yang berkualitas dalam jumlah yang cukup. Tetapi penanganan perbanyakan tanaman sering diabaikan oleh petani tradisional, padahal perbanyakan tanaman yang tepat akan menguntungkan usahatani. Tanaman jambu air dapat diperbanyak secara generatif (biji) dan vegetatif (okulasi, cangkok, stek). Perbanyakan tanaman dengan biji sering mengecewakan karena selain umur mulai berbuah lama (panjang) juga sering terjadi penyimpangan sifat-sifat pohon induknya. Oleh karena itu perbanyakan tanaman jambu air dengan biji hanya dianjurkan untuk memproduksi batang bawah sebagai bahan penyambungan (Rukmana, 1997). 
Perbanyakan vegetatif pada tanaman buah-buahan dimaksud untuk mempertahankan sifat induk yang unggul, memperpendek masa vegetatif, sehingga tanaman tersebut dapat lebih cepat berproduksi. Perbanyakan vegetatif dengan setek sebetulnya paling efisien karena tidak memerlukan batang bawah seperti halnya dengan okulasi atau enten dan waktu yang dibutuhkan relatif singkat. Jika dibandingkan dengan perbanyakan generatif memerlukan waktu yang lebih lama (Anwarudin, Titin, dan Hendro, 1985).

$$
\text { Masalah utama dalam }
$$

penyetekan adalah sulit terbentuknya akar, dan salah satu usaha untuk meningkatkan kemampuan stek membentuk akar yaitu dengan memberikan zat pengatur tumbuh (ZPT). Zat pengatur tumbuh ada 6 kelompok yaitu auksin, sitokinin, giberelin atau asam giberelat, etilena, asam absisat, dan inhibator (Keosriningrum dan Setiaty, 1993).

Auksin adalah zat hormon tumbuhan yang ditemukan pada ujung batang, akar, dan pembentukan bunga yang berfungsi sebagai pengatur pembesaran sel dan memicu pemanjangan sel di daerah belakang meristem ujung. Pertumbuhan akar pada stek memerlukan zat pengatur tumbuh yang bersifat merangsang pembentukan akar (Sandra, 2011).

Riboflavin dan thiamin adalah contoh senyawa yang merupakan bahan baku auksin. Fungsi dari riboflavin memacu inisiasi akar pada stek batang dan akar lateral dalam pengembangan akar sehingga memacu pembelahan sel, pertumbuhan tunas dan tunas samping serta mencegah penuaan dan gugur daun. Sedangkan thiamin berfungsi untuk mempercepat pembelaan sel pada meristem akar dan mengurangi resiko kegagalan pertumbuhan bibit stek. (Muliana dalam Dede, 2014).

Zat pengatur tumbuh dari golongan auksin yang dapat memacu pembentukan akar pada stek antara lain menggunakan ekstrak bawang merah. Umbi bawang merah mengandung vitamin B1 (thiamin), riboflavin serta ZPT auksin dan rhizokalin. Dari setiap 100 gram umbi bawang merah kandungan airnya mencapai 80-85 gram, protein $1,5 \mathrm{~g}$, lemak $0,3 \mathrm{~g}$, karbohidrat 9,3 g, thiamin $30 \mathrm{mg}$, riboflavin $0,04 \mathrm{mg}$, niasin $20 \mathrm{mg}$ (Rahayu dan Berlian, 1999 dalam Siskawati, 2013). Kandungan senyawa dalam 100 gram umbi bawang putih antara lain thiamin $0,22 \mathrm{mg}$, riboflavin $0,11 \mathrm{mg}$, niasin $0,7 \mathrm{mg}$ dan asam pantotenat 0,596 mg (Dede, 2014). Thiamin dan riboflavin pada bawang merah merupakan auksin alami dan sebagai bahan baku sintesis IAA (Soeprapto, 1992 dalam Wibawa, 2010).

Setyowati (2004) melakukan penelitian untuk mengetahui pengaruh ekstrak bawang merah dan bawang putih terhadap pertumbuhan stek bunga mawar menyimpulkan bahwa dalam ekstrak bawang merah mengandung senyawa allithiamin yang dapat mempengaruhi proses fisiologi pada stek mawar karena allithiamin mudah di serap oleh tubuh tanaman, sedangkan tanaman bawang putih mengandung hormon scordinin yang kandungannya setara dengan auksin yang efektif dalam 
proses germinasi dan pengeluaran akar. Hasil uji menunjukkan pemberian ekstrak bawang merah dengan konsentrasi $75 \%$ dan ekstrak bawang putih dengan konsentrasi $60 \%$ yang direndam selama 12 jam memberikan hasil terbaik untuk pertumbuhan panjang akar $(4,83 \mathrm{~cm})$, panjang tunas $(1,92 \mathrm{~cm})$ dan jumlah tunas $(6,20)$. Pada kombinasi ekstrak bawang merah $60 \%$ dan ekstrak bawang putih $75 \%$ memberikan hasil terbaik untuk jumlah daun (12,15 helai). Sedangkan pemberian ekstrak bawang merah 90\% dan ekstrak bawang putih $75 \%$ memberikan hasil terbaik untuk luas daun $\left(2,81 \mathrm{~cm}^{2}\right)$.

Ghawa (2014) melakukan penelitian terhadap pertumbuhan stek kopi yang direndam selama 6 jam, 12 jam dan 24 jam menggunakan ekstrak bawang merah. Hasilnya menunjukkan aplikasi ekstrak bawang merah $90 \%$ memberikan respon terbaik pada lama perendaman 12 jam. Dengan konsentrasi ekstrak bawang merah $90 \%$ menghasilkan persentase stek hidup mencapai $88,89 \%$, tinggi tunas 15,95 $\mathrm{cm}$, jumlah daun 6,33 helai, panjang akar $13,75 \mathrm{~cm}$, berat segar tunas $2,23 \mathrm{~g}$ dan berat kering tunas $1,48 \mathrm{~g}$.

Dede Ahmad, dkk (2014) melakukan penelitian terhadap perakaran tanaman krisan potong dengan memanfaatkan ekstrak bawang merah dan ekstrak bawang putih. Dari hasil pengamatan diperoleh data bahwa rata-rata jumlah akar terbanyak terdapat pada perlakuan menggunakan ekstrak bawang merah $(22,0)$, disusul perlakuan menggunakan bawang putih $(18,5)$ dan yang terakhir perlakuan kontrol $(14,3)$.
Sedangkan data rata-rata panjang akar terbanyak pada perlakuan menggunakan ekstrak bawang merah $(1,73 \mathrm{~cm})$, disusul perlakuan menggunakan ekstrak bawang putih $(1,58 \mathrm{~cm})$, dan perlakuan kontrol $(1,43 \mathrm{~cm})$.

Bawang bombai (Allium cepa $\mathrm{L}$ ) merupakan jenis bawang yang banyak dibudidayakan dipakai sebagai bumbu maupun bahan masakan berbentuk bulat, besar dan berdaging tebal. Dalam setiap 100 gram umbi bawang bombai kandungan air mencapai 87,5 gram, protein $1,8 \mathrm{~g}$, lemak $0,2 \mathrm{~g}$, karbohidrat $10,8 \mathrm{~g}$, thiamin (vitamin B1) $0,03 \mathrm{mg}$, riboflavin (vitamin B2) $0,02 \mathrm{mg}$, niasin $0,4 \mathrm{mg}$, fosfor $(\mathrm{P}) 44 \mathrm{mg}$, besi $(\mathrm{Fe}) 0,7$ $\mathrm{mg}$, serta vitamin C 9,0 mg. (Supriyati, 2010 dalam Sandra, 2011)

Berdasarkan kerangka berpikir di atas, peneliti ingin mengetahui pengaruh penggunaan auksin yang berasal ekstrak bawang merah, ekstrak bawang putih dan ekstrak bawang bombai pada pertumbuhan stek jambu air (Syzygium samarangense), dan Ekstrak yang mempunyai pengaruh yang terbaik terhadap pertumbuhan stek batang jambu air (Syzygium samarangense).

Adapun Hipotesis yang bisa peneliti usulkan adalah : Penggunaan zat pengatur tumbuh auksin alami ekstrak bawang merah, ekstrak bawang putih dan ekstrak bawang bombai diduga berpengaruh pada pertumbuhan stek jambu air, dan Diduga ekstrak bawang merah sebagai zat pengatur tumbuh auksin alami memberikan pertumbuhan akar terbaik pertumbuhan stek batang jambu air. 


\section{METODE PENELITIAN}

\section{Tempat dan Waktu Penelitian}

Penelitian ini dilaksanakan selama 5 (lima) bulan Februari - Juli 2017 di kebun percobaan Fakultas Pertanian Universitas Flores, Kelurahan Lokoboko, Kecamatan Ndona, Kabupaten Ende.

\section{Rancangan Penelitian}

Penelitian dilaksanakan dengan menggunakan Rancangan Acak Kelompok (RAK) dengan 1 (satu) faktor yang terdiri dari 4 (empat) perlakuan yang diulang sebanyak 5 kali, dimana masing-masing perlakuan terdapat 7 tanaman (polybag) sehingga dalam penelitian ini terdapat 140 tanaman (polybag). Adapun perlakuan penelitian untuk satu ulangan adalah sebagai berikut:

$\mathrm{A}_{0}=$ Kontrol (100\% air)

$\mathrm{A}_{1}=$ Ekstrak Bawang Merah 90\% + $10 \%$ air

$\mathrm{A}_{2}=$ Ekstrak Bawang Putih $90 \%+10 \%$ air

$\mathrm{A}_{3}=$ Ekstrak Bawang Bombai 90\% + $10 \%$ air

Jadi, untuk masing-masing perlakuan menggunakan ekstrak bawang 90\% dibutuhkan bahan sebanyak $270 \mathrm{ml}$ ditambah air $30 \mathrm{ml}$ sehingga, kebutuhan masing-masing ekstrak bawang untuk 5 kali ulangan sebanyak $1350 \mathrm{ml}$.

\section{Pelaksanaan Penelitian}

1. Pembuatan ekstrak auksin alami masing-masing dari bawang merah (5 kg, bawang putih $(6 \mathrm{~kg})$, dan bawang Bombay (4 kg). dimana cara pembuatannya adalah sebagai berikut : masing-masing umbi dikupas lalu dicuci dan kering anginkan umbi, kemudian masukkan ke blender secara terpisah, lalu peras dan disaring dengan saringan. Didapatkan Ekstrak bawang masing-masing $1500 \mathrm{ml}$.

2. Persiapan stek jambu air : Bahan stek diambil dari cabang yang sudah dewasa, panjang potongan stek $15 \mathrm{~cm}$ dengan satu pasang daun yang dipotong $2 / 3$ bagian. Pangkal stek dipotong miring $45^{\circ}$ agar memberikan bidang perakaran yang lebih luas. Masing-masing perlakuan dibutuhkan 7 stek jambu air dan jumlah untuk 20 perlakuan dibutuhkan 140 stek tanaman jambu air.

3. Persiapan media tanam : Media tanam yang digunakan terdiri dari campuran tanah (top soil) dan pupuk kompos dengan perbandingan $1: 1$, kemudian diayak dengan ayakan berdiameter $2 \mathrm{~mm}$, campuran tersebut dimasukkan ke dalam polybag ukuran $25 \times 25 \mathrm{~cm}$.

4. Pembuatan naungan dan sungkup : Naungan dibuat dari bambu yang tertutup plastik dengan ukuran panjang 4 meter, lebar 3 meter, tinggi 1,2 meter. Sedangkan sungkup dengan ukuran tinggi 60 $\mathrm{cm}$ dan lebar $2 \mathrm{~m}$.

5. Aplikasi Ekstrak : Aplikasi ekstrak dilakukan dengan konsentrasi ekstrak $90 \%$ dan tambahan air $10 \%$. Sehingga setiap ekstrak terdiri dari $300 \mathrm{ml}$ larutan yang berasal dari $270 \mathrm{ml}$ ekstrak dan $30 \mathrm{ml}$ air, dimana tiap perlakuan diulang 5 
(lima) kali. Cara aplikasinya, dengan merendam stek jambu air dalam masing-masing wadah yang sudah diberi larutan ekstrak selama 12 jam.

6. Penanaman : Setelah batang stek direndam dalam bahan sesuai perlakuan, selanjutnya ditanam ke dalam polybag yang telah tersedia. Stek ditanam dengan posisi tegak lurus kemudian ditempatkan dalam naungan plastik untuk menjaga kelembaban.

7. Pemeliharaan : Pemeliharaan stek dilakukan setelah stek berumur satu bulan karena dalam waktu satu bulan naungan tidak boleh dibuka kecuali kelembaban sudah rendah. Kemudian penyiraman dilakukan secara rutin, penyiangan dilakukan dua minggu sekali.

\section{Variabel Pengamatan}

Pengamatan dilakukan terhadap beberapa variabel atau parameter pertumbuhan meliputi:

a. Persentase stek hidup (\%)

Dihitung jumlah turus yang hidup pada akhir penelitian menggunakan rumus:

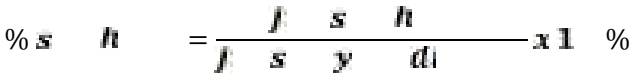

b. Panjang akar (cm)

Diukur dari tempat tumbuhnya akar sampai ujung akar pada umur 30, 45, 60, 75 dan 90 hst.

c. Jumlah akar

Dihitung jumlah akar pada umur 30 , 45, 60, 75 dan 90 hst setelah dibersihkan dari tanah yang menempel.

d. Berat segar akar $(\mathrm{g})$
Seluruh akar yang ada dipotong dari pangkal akar kemudian ditimbang. Berat segar akar ditimbang pada umur 30, 45, 60, 75 dan 90 hst setelah dibersihkan dari tanah yang menempel.

e. Berat kering akar (g)

Caranya akar dikeringkan dalam oven pada suhu $85{ }^{\circ} \mathrm{C}$ selama 28 jam setelah itu dilakukan penimbangan pada umur $30,45,60$, 75 dan 90 hst.

f. Berat brangkasan segar (g)

Menimbang berat brangkasan segar pada umur 30, 45, 60, 75 dan 90 hst.

g. Berat brangkasan kering $(\mathrm{g})$

Caranya tunas dikeringkan dalam oven pada suhu $85{ }^{\circ} \mathrm{C}$ selama 28 jam setelah itu dilakukan penimbangan pada umur $30,45,60$, 75 dan 90 hst.

\section{HASIL DAN PEMBAHASAN}

Berdasarkan hasil analisa sidik ragam, dari keempat perlakuan yaitu tanpa auksin (A-0), ekstrak bawang merah (A-1), ekstrak bawang putih (A2) dan ekstrak bawang bombai (A-3) menunjukkan adanya pengaruh yang signifikan terhadap pertumbuhan akar stek jambu air

Pengamatan terhadap variabel persentase stek hidup dilakukan pada akhir penelitian (90 HST), Hasil analisis sidik ragam menunjukkan bahwa tidak ada interaksi nyata antara pengaruh penggunaan auksin terhadap persentase stek hidup. 


\section{Murdaningsih : Penggunaan Auksin Alami pada Bibit Jambu Air}

Tabel 1. Persentase jumlah stek hidup akibat penggunaan auksin alami

\begin{tabular}{cccc}
\hline Perlakuan & $\begin{array}{c}\text { Stek } \\
\text { hidup }\end{array}$ & $\begin{array}{c}\text { Stek } \\
\text { mati }\end{array}$ & Persentase \\
\hline $\mathrm{A}-0$ & 8 & 7 & 96,00 \\
$\mathrm{~A}-1$ & 3 & 2 & 98,86 \\
$\mathrm{~A}-2$ & 1 & 4 & 97,71 \\
$\mathrm{~A}-3$ & 0 & 5 & 97,14 \\
\hline \multicolumn{3}{c}{ BNT 5\% } & \\
\hline
\end{tabular}

Perlakuantanpa pemberian auksin alami dibandingkan dengan perlakuan pemberian auksin alami, dapat mempengaruhi peningkatan rataan total stek hidup, masing-masing dari perlakuan A-0 ke A-1 sebesar 2,99\%; dari perlakuan A-0 ke A-2 sebesar $1,82 \%$ dan dari perlakuan A-0 ke A-3 sebesar $1,19 \%$.

Pada semua parameter pengamatan yaitu panjang akar, jumlah akar, berat segar akar, berat brangkasan segar dan berat brangkasan kering, menunjukkan adanya perbedaan yang nyata dan perlakuan penggunaan ekstrak bawang merah menunjukkan hasil yang terbaik.

Pada Variabel pengamatan panjang akar, menunjukkan peningkatan rataan total panjang akar dengan pemberian auksin alami,secara berturut-turut antara perlakuan A-0 (tanpa auksin) ke A-1 (bawang merah 90\%) sebesar 51,22\%; antara perlakuan A-0 ke A-2 (bawang putih 90\%) sebesar $37,72 \%$ dan antara perlakuan A-0 ke A3 (bawang bombai 90\%) sebesar $17,68 \%$ (Gambar1); untuk variable jumlah akar dapat meningkatkan rataan total jumlah akar secara berturut-turut sebesar 56,55\%; 35,84\% dan 29,32\% (Gambar 2), demikian juga untuk parameter berat segar akar dapat meningkatkan rataan sebesar 47,54\% (A0 ke A1); 27,05\% (A0 ke A2) dan 14,35\% (A0 ke A3) (Gambar 3); untuk berat kering akar peningkatan perlakuan A0 ke A1 sebesar 51,72\%; perlakuan A0 ke A-2 sebesar 24,54\% dan perlakuan A-0 ke A-3 sebesar 12,55\% (Gambar $4)$.

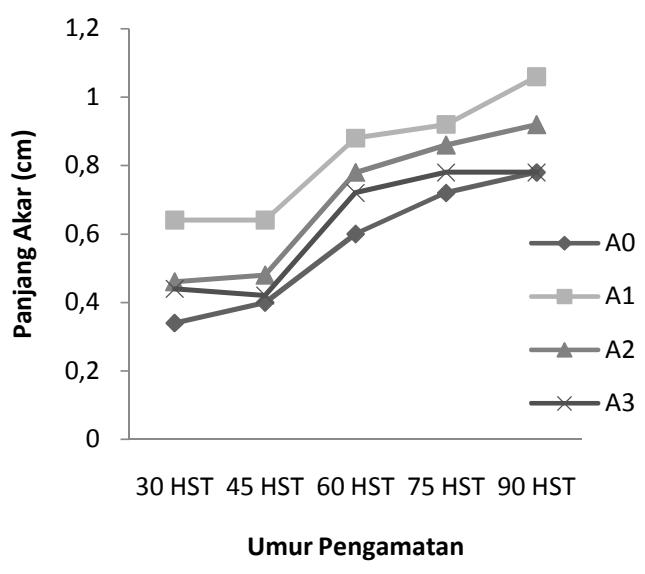

Gambar 1. Pengaruh Ekstrak bawang terhadap panjang akar stek jambu air pada berbagai umur pengamatan

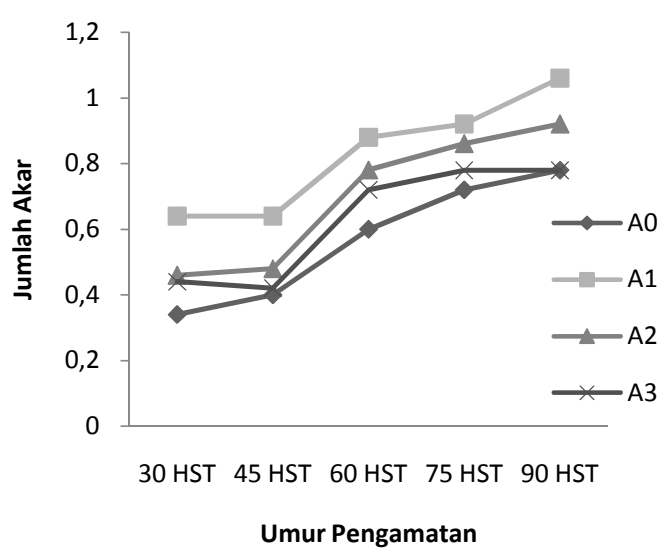

Gambar 2. Pengaruh Ektrak bawang terhadap jumlah akar stek jambu air pada berbagai umur pengamatan 


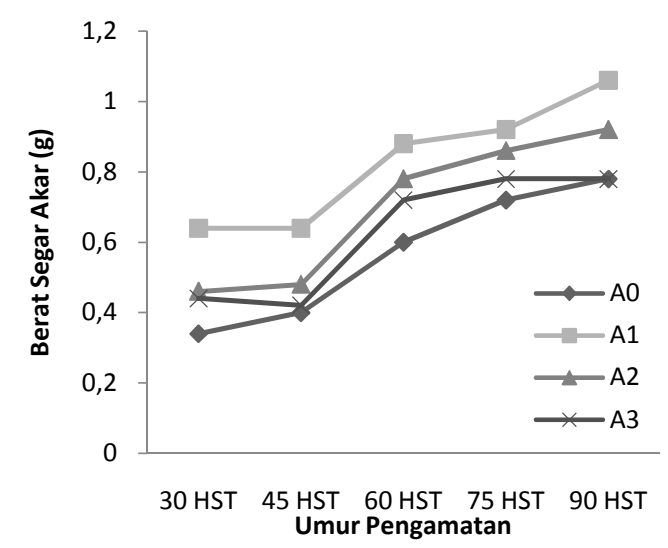

Gambar 3. Pengaruh Ekstrak Bawang terhadap berat segar akar stek jambu air pada berbagai umur pengamatan

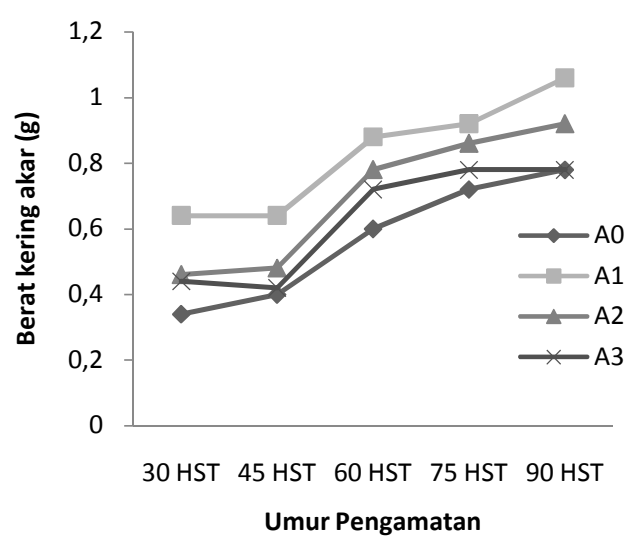

Gambar 4. Pengaruh Ekstrak Bawang terhadap berat kering akar stek jambu air pada berbagai umur pengamatan

Adapun untuk parameter pengamatan berat brangkasan segar peningkatan perlakuan A0 ke A1 sebesar 26,22\%; perlakuan A-0 ke A-2 sebesar 15,69\% dan perlakuan A-0 ke A-3 sebesar $4,55 \%$ (Gambar 5); sedangkan peningkatan berat kering brangkasan perlakuan A0 ke A1 sebesar 27,64\%; perlakuan A-0 ke A-2 sebesar 16,41\% dan perlakuan A-0 ke A-3 sebesar $6,44 \%$ (Gambar 6 ).

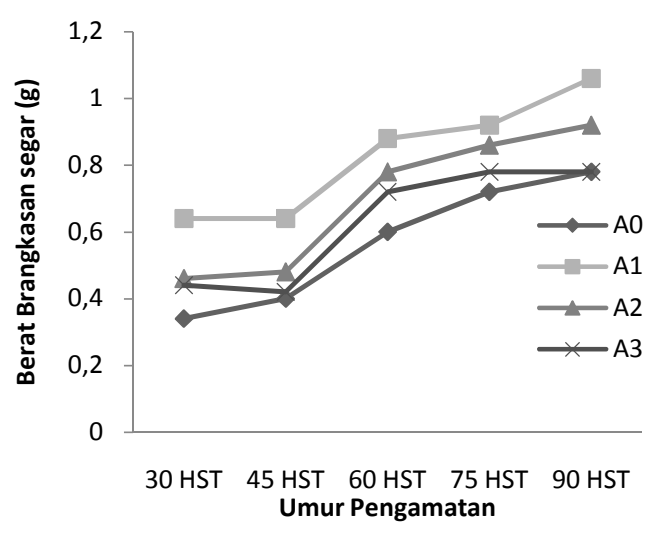

Gambar 5. Pengaruh Ekstrak Bawang terhadap berat brangkasan segar stek jambu air pada berbagai umur pengamatan

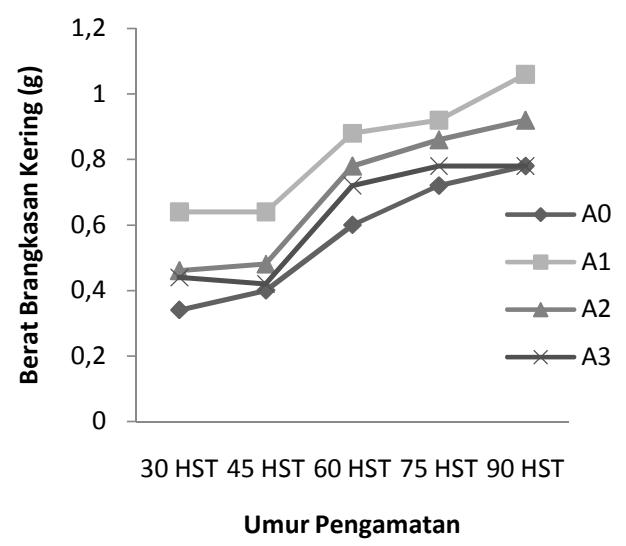

Gambar 6. Pengaruh Ekstrak Bawang terhadap berat brangkasan kering stek jambu air pada berbagai umur pengamatan

Peningkatan pada semua parameter pengamatan menunjukkan bahwa hipotesis pertama (1) terbukti dimana pemberian auksin alami ekstrak bawang merah 90\%, bawang putih $90 \%$ dan bawang bombai $90 \%$ memberikan pengaruh positif dan signifikan terhadap stek jambu air. Umbi bawang merah mengandung vitamin B1 (thiamin), riboflavin serta ZPT auksin dan rhizokalin. Thiamin dan riboflavin pada bawang merah merupakan auksin alami 


\section{Murdaningsih : Penggunaan Auksin Alami pada Bibit Jambu Air}

dan sebagai bahan baku sintesis IAA (Soeprapto, 1992 dalam Wibawa, 2010). Umbi bawang merah mengandung thiamin $30 \mathrm{mg} / 100 \mathrm{~g}$ dan riboflavin 0,04 mg/100 g (Rahayu dan Berlian, 1999 dalam Siskawati, 2013) setara dengan thiamin $42,86 \mathrm{mg} / \mathrm{tan}$ dan riboflavin $0,06 \mathrm{mg} / \mathrm{tan}$. Kandungan auksin alami dalam bawang putih berupa thiamin $0,22 \mathrm{mg} / 100 \mathrm{~g}$ dan riboflavin $0,11 \mathrm{mg} / 100 \mathrm{~g}$ setara dengan thiamin $0,38 \mathrm{mg} / \tan$ dan riboflavin 0,19 mg/tan sedangkan dalam ekstrak bawang bombai mengandung thiamin $0,03 \mathrm{mg} / 100 \mathrm{~g}$ dan riboflavin 0,02 $\mathrm{mg} / 100 \mathrm{~g}$ (Supriyati, 2010) yang setara dengan thiamin $0,034 \mathrm{mg} / \mathrm{tan}$ dan riboflavin $0,022 \mathrm{mg} / \mathrm{tan}$.

Berat basah dan berat kering brangkasan tanaman dipengaruhi oleh banyaknya jumlah daun, jumlah akar, panjang akar dan diameter batang yang tumbuh. Weaver (1982) menyatakan bahwa semakin luas bidang penyerapan akar maka akan semakin banyak air dan unsur hara yang diserap sehingga mempengaruhi berat basah dan berat kering brangkasan tanaman. Berat basah dan berat kering brangkasan yang rendah berkaitan dengan rendahnya jumlah daun dan jumlah akar yang dihasilkan. Jumlah daun dan akar yang sedikit, berhubungan dengan hasil fotosintesis dan kandungan air serta unsur-unsur hara yang diserap oleh akar.

Hasil pengamatan terhadap
semua variabel pengamatan
menunjukkan hipotesis kedua (2) juga
terbukti dimana perlakuan
menggunakan ekstrak bawang merah
$90 \% \quad$ (A-1) menunjukkan hasil

terbaikuntuk semua umur pengamatan. Hal ini dipengaruhi oleh kadar auksin alami dimana bawang merah mengandung thiamin $30 \mathrm{mg} / 100 \mathrm{~g}$ dan riboflavin 0,04 mg/100 g (Rahayu dan Berlian, 1999 dalam Siskawati, 2013) setara dengan thiamin $42,86 \mathrm{mg} / \tan$ dan riboflavin $0,06 \mathrm{mg} / \mathrm{tan}$. Kandungan auksin alami dalam bawang putih berupa thiamin $0,22 \mathrm{mg} / 100 \mathrm{~g}$ dan riboflavin $0,11 \mathrm{mg} / 100 \mathrm{~g}$ setara dengan thiamin $0,38 \mathrm{mg} / \tan$ dan riboflavin 0,19 $\mathrm{mg} / \mathrm{tan}$ sedangkan dalam ekstrak bawang bombai mengandung thiamin $0,03 \mathrm{mg} / 100 \mathrm{~g}$ dan riboflavin 0,02 $\mathrm{mg} / 100 \mathrm{~g}$ (Supriyati, 2010) yang setara dengan thiamin $0,034 \mathrm{mg} / \mathrm{tan}$ dan riboflavin $0,022 \mathrm{mg} / \mathrm{tan}$. Umbi bawang merah mengandung vitamin B1 (thiamin), riboflavin serta ZPT auksin dan rhizokalin. Thiamin dan riboflavin pada bawang merah merupakan auksin alami dan sebagai bahan baku sintesis IAA (Soeprapto, 1992 dalam Wibawa, 2010).

Lakitan (1996) menyatakan bahwa berat basah dan berat kering brangkasan merupakan cerminan akumulasi berupa air dan unsur-unsur hara yang diserap untuk pertumbuhan stek. Berat brangkasan berkaitan dengan jumlah daun dan jumlah akar yang dihasilkan. Jumlah daun dan akar yang sedikit, berhubungan dengan hasil fotosintesis dan kandungan air serta unsur-unsur hara yang diserap oleh akar.

Hasil penelitian Siskawati, dkk (2013) menyimpulkan pemberian ekstrak bawang merah menghasilkan jumlah daun terbanyak dengan rerata 10,46 helai daun. Ekstrak bawang 
merah yang mengandung auksin dan vitamin B1 (thiamin) dapat memacu pembelahan sel pada stek batang jarak pagar. Auksin dan vitamin B1 yang terdapat dalam ekstrak bawang merah mampu untuk merangsang pertumbuhan akar dan tunas (Rahayu dan Berlian, 1999).

\section{SIMPULAN DAN SARAN}

\section{Simpulan}

Berdasarkan hasil analisis data yang telah dilakukan maka dapat disimpulkan beberapa hal antara lain:

1. Berdasarkan hasil analisis, penggunaan auksin ekstrak bawang merah 90\%, dapat meningkatkan persentase stek hidup (2,99\%), panjang akar $(51,22 \%)$; jumlah akar $(56,55 \%)$, berat segar akar $(47,54 \%)$; berat brangkasan segar (26,22\%); berat kering akar $(51,72 \%)$ dan berat brangkasan kering $(27,64 \%)$.

2. Penggunaan ekstrak bawang merah 90\% memberikan pengaruh terbaik terhadap pertumbuhan akar stek jambu air yang menghasilkan persentase stek hidup (98,86\%); panjang akar $(10,04 \mathrm{~cm})$; jumlah akar $(19,20)$; berat segar akar $(2,02$ $\mathrm{g})$; berat brangkasan segar $(17,22$ g); berat kering akar (1,06 g) dan berat brangkasan kering $(8,60 \mathrm{~g})$.

\section{Saran}

Berdasarkan hasil penelitian, maka penulis dapat memberikan beberapa saran dan rekomendasi antara lain:
1. Sebagai upaya pemenuhan kebutuhan akan bibit tanaman jambu air, maka disarankan upaya perbanyakan bibit secara vegetatif dengan memanfaatkan auksin alami yang terkandung dalam ekstrak bawang merah.

2. Bagi peneliti selanjutnya, dapat meneliti penggunaan auksin bawang merah ditinjau dari lama perendaman untuk melihat pertumbuhan akar tanaman dari stek batang.

\section{UCAPAN TERIMA KASIH}

Penelitian ini dapat dilaksanakan karena adanya beberapa pihak yang mendukung kami, untuk itu perkenankanlah kami menyampaikan ucapan terimakasih kepada :

1. Dekan Fakultas Pertanian, Wakil Dekan, Ketua Program Studi dan segenap jajarannya yang sudah memberikan dukungan

2. Dosen-dosen yang sudah memberikan kritik dan saran untuk kesempurnaan tulisan ini.

3. Teman-teman yang sudah terlibat dan membantu Penelitian ini

\section{DAFTAR PUSTAKA}

Dede, A., Nurmala,N., Nurlatifah. 2014. Pemanfaatan Ekstrak Bawang (Allium Cepa dan Allium Sativum) Sebagai Hormon Alami Perangsang Pertumbuhan Perakaran Krisan Potong (Chrysanthemum sp)". Artikel Ilmiah Program Kreativitas 
Murdaningsih : Penggunaan Auksin Alami pada Bibit Jambu Air

Mahasiswa Bidang Kegiatan

PKM Universitas Pendidikan

Indonesia Bandung.

Ghawa, R.P. 2014. Pengaruh

Penggunaan Macam Sumber

Auksin dan Lama Perendaman

Terhadap Stek Kopi. Skripsi

Fakultas Pertanian Institut

Pertanian Stiper Yogyakarta.

Hasanah, F. N., Setiari, N. 2007.

Pembentukan akar pada stek batang nilam (Pogostemoncablin Benth.) setelah direndam IBA (indole butyric acid) pada konsentrasi berbeda. Buletin Anatomi dan Fisiologi. Volume 15, Nomer 2:1-6

Husniati, K. 2010. Pengaruh Media Tanam Dan Konsentrasi Auksin Terhadap Pertumbuhan Stek Basal Daun Mahkota Tanaman Nenas (Ananas comosus L. Merr). Skripsi Program Studi Pemuliaan Tanaman dan Teknologi Benih. IPB. Bogor.

Purwitasari, W. 2004. Pengaruh Perasan Bawang Merah (Allium ascalonicum L.) Terhadap Pertumbuhan Akar Stek Pucuk Krisan (Chrysanthemum sp). Skripsi Jurusan Biologi Fakultas Matematika dan Ilmu Pengetahuan Alam. Universitas Diponegoro, Semarang.

Sandra, E. 2011. Hormon dan Pertumbuhan Tanaman. Online: http://eshaflora.blogspot.com/hor mon_dan_pertumbuhan_tanama n. Diakses 14 Januari 2015

Sekta. N.D. 2005. Aplikasi Ekstrak Bawang Merah dan Air kelapa Muda pada Pertumbuhan
BibitStek Cabe Jawa (Piper retrofractum Vahl.). Online: http://www.bdpunib.org. Diakses 15 Januari 2015

Setyowati, T. 2004. Pengaruh Ekstrak Bawang Merah (Allium cepa L) dan Ekstrak Bawang Putih (Allium sativum L) Terhadap Pertumbuhan Stek Bunga Mawar (Rosa sinensis L). Undergraduate Thesis Departemen Biologi Universitas Muhammadiyah Surakarta.

Siskawati, E., Linda, R., Mukarlina. 2013. Pertumbuhan Stek Batang Jarak Pagar (Jatropha curcas L.) dengan Perendaman Larutan Bawang Merah (Allium cepa L.) dan IBA (Indol Butyric Acid). Jurnal Protobiont Vol. 2 (3): 167-170 Program Studi Biologi, Fakultas MIPA Universitas Tanjungpura - Pontianak

Sulastri, Y. S. 2004. Pengaruh Konsentrasi Indole Butyric Acid (IBA) dan Lama Perendaman Terhadap Pertumbuhan Setek Pucuk Jambu Air (Syzygium semarangense Burm. F. Alst). Jurnal Penelitian Bidang Ilmu Pertanian Universitas Katolik St. Thomas Sumatera Utara. Volume 2, Nomor 3, Desember $2004: 25-34$

Wibawa, B. 2010. Pengaruh Ekstrak Touge Kacang Hijau Terhadap Perkecambahan Seledri (Apiumgraveolens L.). Skripsi Tidak Diterbitkan Jurusan Biologi Universitas Jambi. 